\title{
Librarians and the Bipolarization of the Academic Enterprise
}

\author{
By DANIEL PATRICK BERGEN
}

Nearly four years ago, C. P. Snow took time to describe for us the gulf separating the physical scientists from the literateurs. ${ }^{1}$ Few of us will soon forget the shocking message contained in his little book, The Two Cultures and the Scientific Revolution. One wonders, however, how many academic librarians have perceived an analogous chasm separating themselves from the classroom faculty. It will be the purpose of this paper to demonstrate that librarians and teachers belong to different, often mutually exclusive, subcultures within the collegiate setting. $^{2}$ Furthermore, it will be suggested that the initiatives for any convergence of these disparate subcultures must come, by and large, from the subculture of the librarians.

To begin this analysis of hypothetical subcultures, it will be useful to view the college or university as a social system, defined by Talcott Parsons as "the specifically relational system of interaction among individuals and collectivities."3 The institution of higher education provides an arena within which, ideally, teachers and librarians should interact. ${ }^{4}$

\footnotetext{
1 The Rede Lecture for 1959 (New York: Cambridge University Press, 1959).

${ }^{2}$ Cultures, consequently subcultures, are ordinarily distinguished along three dimensions: (1) values; (2) ideas; and (3) expectations. Obviously, subcultures strongly shape the behavior of their human membership.

${ }^{3}$ Talcott Parsons and Alfred L. Kroeber, "The Concepts of Culture and of Social System," American Sociological Review, XXIII (October 1958), 582-83.

-During a discussion on teaching at the University of Wisconsin, the famous Professor Mark Ingraham was once asked whether one could best understand the teaching process by beginning with a consideration of its nature and purpose. His response well illustrates the importance of viewing the college or university as an operating context. The elaboration of his negative reply took this form: "It is better to begin with the
}

Mr. Bergen is a doctoral candidate in the Graduate Library School, University of Chicago.

Any social system, whether it be a college or a factory, or even a small underdeveloped country, has four major functions: (1) the adaptive function; (2) the goalattainment function; (3) the patternmaintenance and tension-management function; and (4) the integrative function. ${ }^{5}$ Regardless of his formal position and the nature of the service situation, the individual librarian tends to expend most of his effort on but one of these social system functions. Technical services personnel who have become administrators often continue to be dominated by a procedural perspective toward academic librarianship. Such librarians persist, in their concern for efficiency and output, in emphasizing the goal-attainment function, ${ }^{6}$ even when energy and thought might be more fruitfully directed to adapting the library to the rest of the social system or promoting interpersonal relationships between librarians and teachers. The librarian who is a subject specialist may forfeit a great opportunity to contribute to the integrative function

nature of a college, and to derive from its community of learners, its intellectual priorities, its quest of knowledge, its reciprocal modes, that sense of context in which a teacher can answer his own question." Quoted in Arthur J. Dibden, "The Academician as Teacher," Liberal Education, XLVIII (May 1962), 198.

s For a graphic illustration of these four functions, see Talcott Parsons, "General Theory in Sociology" in Robert K. Merton, Leonard Broom, and Leonard S. Cottrell (eds.), Sociology Today: Problems and Pros. pects (New York: Basic Books, 1959), p. 7.

'Jacques Barzun, teacher and administrator, con. tends that the goals of most librarians continue to be oriented to conservation. See his Teacher in America (Garden City, N.Y.: Doubleday, 1954), p. 70. 
of the social system by being overly conceptual (i.e., ideological) and succumbing to the temptation to be educative when instruction is not relevant. Finally, a reference or acquisitions librarian, after some experience in neutrally mediating the information or materials needs of competing groups on the campus, is likely to develop a contextual outlook, that is, a relatively accurate notion of the library's role in the institutional constellation. When this kind of librarian becomes an administrator, he is conditioned, in most cases, to a more rational allocation of efforts among the adaptive, integrative, and pattern-maintenance/tension-management functions than is a librarian with less experience in reconciling the diverse interests and needs of elements within the institution. This last described and most realistic of academic librarians should administratively outperform his more mechanistic (procedure-oriented) and idealistic (education-oriented) counterparts. ${ }^{7}$ Among librarians he has the greatest potential for developing effective colleagueship with the teaching faculty. Most significantly, however, by emphasizing nongoal-attainment functions he is likely ultimately to accomplish more for the institution his library serves than those librarians who are obsessed with the intra-library ends of efficiency and production.

Forces in higher education have, over the years, changed the image of both professors and academic librarians. The wide availability of reading materials and the heightening of professorial demands upon students to use the library have tended to reorient the rationale of academic librarianship from preservation to a combination of preservation and use. The definition of a college professor's functions has undergone as great

"For this taxonomy of librarianship (i.e., realistic, idealistic, and mechanistic), I am indebted to J. Z. Nitecki of the Wilson Junior College, Chicago. His philosophy of librarianship will be further developed in a proposed master's thesis at the Graduate Library School of the University of Chicago, "A Theory of Public Interest in the Philosophy of Librarianship." a metamorphosis. ${ }^{8}$ The era has long passed when a teacher was just that and no more. In addition to teaching, he is now called upon to do research and to develop student character through the inculcation of values acceptable to society, ${ }^{9}$ not to mention the responsibility of those in public institutions to provide various kinds of service to citizens of the state, region, or municipality. Increasingly, however, research and writing receive primary emphasis in institutions of higher education. Unlike classroom teaching, research is professionalized and is largely under faculty control; its fruits can be evaluated and assessed by the academic peers of the researcher. ${ }^{10} \mathrm{By}$ contrast, classroom teaching is not governed by professional canons or standards and, in the usual absence of adequate faculty control, is subject to the encroaching interference of the administration or the governing board of the institution. The old image of the scholar as "moralist, librarian, and detective" has by and large been replaced by the concept of the scholar as entrepreneur. Successful books, patents, grants, and consulting positions not only increase one's personal income and prestige, but are as well those things which colleges and universities most actively promote. In a scheme of values where "status for the scholar means status for the school," the academician more and more assumes the coloration of the successful American businessman.11 Indeed, the professor who does not actively pursue research tends to be looked upon

\footnotetext{
${ }^{8}$ According to the Harvard historian, Samuel Eliot Morison, the term "scholar" originally meant simply "a child attending school" as in the old nursery rhyme, "A dillar, a dollar, a ten o'clock scholar." See his The Scholar in America: Past, Present, and Future (New York: Oxford University Press, 1961), p. 1.

Robert H. Knapp, "Changing Functions of the College Professor" in Nevitt Sanford (ed.), The American College: A Psychological and Social Interpretation of the Higher Learning (New York: Wiley, 1962), p. 292.

${ }^{10}$ Burton R. Clark, "Faculty Authority," American Association of University Professors Bulletin, XLVII (Winter 1961), 295.

1 Arthur J. Dibden, "The Academician as Scholar," Liberal Education, XLVIII (March 1962), 11-12, Jacques Barzun has observed that to teach without doing research is now viewed as "a fool's way to man. age a career." See ibid., p. 12, for this quotation.
} 
as a functionless ornament in the academic environment. ${ }^{12}$

On the negative side, it is ever more apparent that those who imported the university idea from Germany neglected to appropriate, along with it, the notion of the gymnasium with its community of scholars sharing a common background in the liberal arts. Those teachers who find greater possibilities for advancement by doing research in their specialized subjects than in direct service to their institutions (e.g., planning, committee work, etc.) can be expected to have little in common with one another. Robert Maynard Hutchins is correct, it would seem, in suggesting that a university is no longer a community of scholars because, as he indicates, that type of community "if it ever existed, has now collapsed." 13 The doctrine of publish or perish strongly supports those professors who would seek national and international status in their disciplines, and rebuffs those who would prefer to devote themselves to improving the university locales. In fact, the orientation of the disciplinary cosmopolitans is so strongly extra-institutional that there has been a substantial moderation of the tensions traditionally found in academic departments. ${ }^{14}$ To be sure, there are still some campus-oriented elder statesmen around, but, given the national orientation of most younger scholars, the localism they espouse will become even more residual upon their retirement. ${ }^{15}$ Somewhat curiously, a significant measure of localism probably coexists with strong cosmopolitanism in universities of high aca-

12 Indeed, as Robert H. Knapp has pointed out, a positive enthusiasm for teaching can seem a bit odd in our day. See Knapp, loc. cit., p. 298.

13 Robert M. Hutchins, "An Appraisal of American Higher Education," School and Society, XC (May 5, 1962), 216.

14 One seems to hear less these days of the Conservatives vs. the Liberals, the Young Turks vs. the Elder Statesmen, the Inbreds vs. the Outbreds, or the ProAdministration Bloc vs. the Anti-Administration Bloc. For a complete list of these traditional departmental divisions, see Theodore Caplow and Reece J. McGee, The Academic Marketplace (New York: Basic Books, 1958), p. 193.

15 Ibid., p. 85 . demic quality. In such schools, cosmopolitanism is so powerful and overarching that it becomes different and fashionable to develop an attraction to one's own institution. Such universities (e.g., Harvard, Princeton, Chicago, Stanford, etc.) invariably possess exciting and rich traditions, and their national prestige renders them entirely capable of serving as a status referent. On balance, teachers who congregate in such institutions have received their advanced degrees from universities of equal repute, ${ }^{16}$ and, as John G. Darley has determined, their "image of the academic life converges toward a single standard of expectation...."17

Academic librarians, contrasted with teachers, are likely to have a strong collegiate or institutional orientation. The library administrator, unless he teaches or does research, may find that what status he has is derived almost completely from his university's administrative status system. ${ }^{18}$ As a national discipline, librarianship is too fractured and ill-formulated to possess the powers of statusconferral which presently inhere in the subject disciplines. There is little way at present for the academic librarian who is

10 Bernard Berelson, Graduate Education in the United States (New York: McGraw-Hill, 1960), p. 113.

${ }^{17}$ Dr. John G. Darley of the American Psychological Association once suggested that "the graduate schools turn out future college faculty members whose image of the academic life converges toward a single standard of expectation rather than differential standards based on variation in student characteristics among different types of institutions." From T. R. McConnell, A General Pattern for American Public Higher Education (New York: McGraw-Hill, 1962), p. 63. See also David Riesman, "Planning in Higher Education: Some Notes on Patterns and Problems," Human Organiza. tion, XVIII (Spring 1959), 14.

${ }^{18}$ Patricia B. Knapp, "The College Librarian: Sociology of a Professional Specialization," CRL, XVI (January 1955), 69. The U.S. Office of Education has recently sought to determine the head librarian's locus of organization in various types of institutions. In twoyear colleges, head librarians are about evenly organized under presidents and academic deans. In four-year institutions, there is a stronger tendency for the librarian to be assigned to the academic dean. This tendency persists in schools which award advanced degrees. See Archie R. Ayers and John H. Russel, Internal Structure: Organization and Administration of Institutions of Higher Education (Division of Higher Education, U.S. Office of Education, Bulletin 1962, \#9 [Washington: Government Printing Office, 1962]), pp. 54, 56-57. 
not subject competent or skilled in research to be more than ancillary to the discipline-oriented status system of the teaching faculty.

Librarians and teachers also differ in the degree to which they are able to structure their professional activities. The normative system of a college, particularly if it is a good college, is largely a product of professorial thought and activity. David Riesman has observed that:

What is perhaps most characteristic in the work of the college professor is ... that he sets his own goals; the goals are not given by an institution. This is certainly so in the penumbra of freedom beyond his regular teaching and other curricular duties, and even these duties, the higher one rises in the system, are defined in terms of one's own aims and definition of the situation. It is this that makes the professor kin to the artist or writer, who is often seeking to create his own institutional norms; and it is this freedom, I am sure, that attracts many to the profession. ${ }^{19}$

The academic librarian, on the other hand, is forced to operate in a context which is far more rigidly defined and bureaucratically ordered than that of his teaching associate. In a sense, the librarian's strong orientation to the local scene is a partial consequence of the way his working environment restricts his chances for outside contact.

A clear manifestation of the differing perspectives held by librarians and teachers is found in the continuing tension over the centralization of library resources. The librarians, sensitive to the demands of an all-campus constituency, support centralization as a means of maximizing use and accessibility for the

\footnotetext{
19 David Riesman, "The College Professor" in Brand Blanshard (ed.), Education in the Age of Science (New York: Basic Books, 1959), p. 277. W. H. Cowley, the well known historian of higher education at Stanford, has even generalized that "professors have more individual freedom in deciding upon their procedures and in allocating their time and energies than perhaps any other variety of professional people." See his "Professors, Presidents, and Trustees," in Changing Roles and Patterns in Higher Education (Tucson: University of Arizona Press, 1962), p. 58. See also Burton R. Clark, loc. cit., p. 302 .
}

entire institution. The subject departments, bent upon encouraging faculty members to complete research projects for which national recognition can be gained, desire the kind of materials accessibility for the local group that only decentralization can provide. At Harvard, extreme decentralization has tended to promote faculty participation in collection building and has served to identify more closely departmental libraries with the faculty members they serve. $^{20}$ On March 14, 1960, Professor Paul Herman Buck, director of the Harvard University library, made this observation before his institution's Board of Overseers:

Harvard's outstanding library has given the university a significant advantage over other institutions in attracting and holding the best men. Harvard with a second-rate library would not be the Harvard of 1960 minus a few million volumes; it would be a Harvard in which second-rate men had replaced many present members of the faculties and student body. 21

Professor Buck's remarks on the importance of library facilities in the attraction of an outstanding faculty are reinforced by two recent studies of the motivations underlying faculty movements. Researchers at the University of Minnesota have determined that the adequacy of research facilities is a prime factor in attracting faculty personnel to that institution. ${ }^{22}$ And John W. Gustad, analyzing the career decisions of college teachers, found that research ranks at the top in the hierarchy of faculty rewards. ${ }^{23}$ Since proximately available library resources, one supposes, catalyti-

${ }^{20}$ Douglas W. Bryant, "Centralization and Decentralization at Harvard," CRL, XXII (September 1961), 333.

${ }^{21}$ Paul Herman Buck, "The Problems and Objectives of a Great Research Library," Library Journal, LXXXVI (June 1, 1961), 2052-53.

${ }_{2}$ John E. Stecklein and Robert Lathrop, Faculty Attraction and Retention (Minneapolis: Bureau of Institutional Research, University of Minnesota, 1960).

${ }^{23}$ John W. Gustad, The Career Decisions of College Teachers (Atlanta: Southern Regional Education Board, 1960). 
cally encourage research, it may prove interesting to examine a recent exchange between a librarian and a physicist over the positioning of library materials.

The physicist was D. A. Wells, chairman of the department of physics at the University of Cincinnati, and the librarian, Jesse H. Shera, dean of the school of library science at Western Reserve University. Wells, polling 104 of his fellow physics department chairmen, found 81 per cent in favor of departmental library facilities, 16 per cent with no positive comment one way or the other, and but 3 per cent in favor of a centralized science library. ${ }^{24}$ The different arguments used by the department chairmen supporting decentralization may be summarized in this way: (1) highly accessible library facilities attract prospective faculty members; (2) librarians who serve only one science will be more competent than those who must serve a whole range of sciences; and (3) the departments would respond to centralization by developing internally administered collections of research materials on their own. ${ }^{25}$ In his article answering Wells, Dean Shera made the following points: (1) in a decentralized system students and faculty members doing interdisciplinary research are forced to use too many different library locations; (2) librarians do not relish arbitrating between departments, where boundaries are particularly tenuous, over who gets which expensive volumes and periodical files; (3) the money saved by consolidation can mean larger book and periodical budgets for the departments; (4) professional library personnel are not attracted to small departmental libraries; (5) decentralization

2 D. A. Wells, "Individual Departmental Libraries vs. Consolidated Science Libraries," Physics Today, XIV (May 1961), 40. Unfortunately, Wells does not indicate how many of the 104 departments surveyed are now served by departmental library facilities.

${ }^{25}$ Ibid., p. 41. At the University of Michigan, there was majority sentiment in almost all colleges and departments in favor of the system of branch libraries now existing at that university. See University of Michigan Survey Research Center, Faculty Appraisal of a University Library: A Report on the Response of the University of Michigan Faculty to a Mail Ques. results in the duplication of materials and an undesirable diffusion of the responsibility for acquisitions; and (6) centralized library facilities are both amenable to automation and capable of providing book delivery service. ${ }^{26}$

About three years ago, the conflict over centralization (this time over organizational control rather than the locating of library resources) gave indication that it could escalate into a struggle to preserve professional library control over the provision of specialized library service in a university system. The American Bar Association's Section on Legal Education and Admission to the Bar decreed that, unless evidence showing its complete impracticality could be presented, law school libraries should be administered as autonomous units under the dean of the law school rather than as units in integrated university systems under the directors of libraries. ${ }^{27}$ In an address to the Graduate Library School Conference at Chicago in July 1961, Ralph Ellsworth reflected on his bitter opposition to the ABA's strategy of encroachment. Miles O. Price, now retired from his position of law librarian at Columbia, suggested at the time that how the law library of a given university is organized might best be conditioned by the personalities involved (i.e., law dean, law librarian, and director of libraries) rather than by any imposed scheme of formal organization. It was quite clear, however, that Price's sympathies were with integration, and he even suggested that, despite the uniqueness of the law library, a director could still understand its peculiar needs. ${ }^{28} \mathrm{~A}$ strong voice in favor of autonomy was that of Professor Erwin Pollack of Ohio State Univer-

tionnaire Concerning the University Library's Col. lections, Services, and Facilities as of April 1961 (Ann Arbor: University of Michigan Library, 1961), p. 41.

26 Jesse H. Shera, "How Much Is a Physicist's Inertia Worth?," Physics Today, XIV (August 1961), 42 43.

${ }^{27}$ Miles O. Price, "The Place of the Law School Library in Library Administration," Journal of Legal Education, XIII (1960), 220.

${ }^{28}$ Ibid., p. 232. 
sity. He openly regretted that Ellsworth, in his speech before the American Association of Law Librarians, "could not see the distinction between law libraries and other libraries." 29 While Ellsworth thought that the granting of autonomy would isolate the law library from the rest of the system (an undesirable kind of apartheid), Pollack argued that "the proper integration of a law library is into the law school, and not into the university library."30 The real jurisdictional question here was whether the ALA and specifically its Association of College and Research Libraries (though the independent Association of Research Libraries may be involved) is structurally and professionally strong enough to withstand this power play by the ABA. Very clearly, a university president will favor autonomy if there is any real threat to the accredited status of his law school. For the law school that loses its ABA accreditation, the game is over. It would seem that disputes of this kind will ultimately force academic librarians to seek some way of demonstrating the logic in William Kornhauser's injunction that "the tension between the integration and autonomy of professional groups ... tends to insure a more effective structure than is attained where they are isolated from one another or where one absorbs the other." 31

One wonders if tensions, like those described above, could not be reduced if librarians would show themselves more willing to make concessions to the academic departments in the matter of decentralization and to the professional schools in the matter of control over the libraries serving them. To attempt to counter the centrifugal thrust of the faculty, and the units in which the professoriate works, is unrealistic policy. It cannot be emphasized enough that pro-

\footnotetext{
20 Erwin H. Pollack, "Autonomy versus Integration in Law Library Administration: A Reply to Dr. Price," Journal of Legal Education, XIV (1961), 231. so Ibid., p. 232.

s1 William Kornhauser, Scientists in Industry (Berkeley: University of California Press, 1962), p. 197.
}

fessors, not librarians, determine the direction of a university. However much we may romanticize about interdisciplinary research and the integration of knowledge, we should never, as librarians, be oblivious to the overpowering tide of subject specialization. As research grows in importance and as the role of the librarian in the successful prosecution of research becomes more vital, it would be folly for academic librarians to estrange themselves from the teaching faculty simply because they were not willing to make concessions which, in the end, might have only negligible effect on the preservation of professional autonomy.

Making concessions to the faculty will not, of itself, insure for librarians the kind of relationship which ought to exist with the faculty. It is imperative that librarians understand and involve themselves in the ethos (including the folklore) of each discipline they are charged with serving. An important step in the development of identification with an occupation, whether it be librarianship or college teaching, is the acquisition of its ideology. ${ }^{32}$ Faculty members introduce graduate students, in a kind of apprenticeship situation, to those patterns of value and expectation which they should possess as professional members of a particular discipline. Donald L. Thistlethwaite of Vanderbilt University has even detected this kind of socialization and acculturation operating at the undergraduate level where faculty members try to develop motivation in their best students to seek advanced training in a particular discipline. In the pure and applied sciences, for example, faculty personnel exert a press for scientism, compliance, and vocationalism, but little or none for humanism and independence. The press situation in the humanities and social sciences, on the other

${ }^{32}$ For a step-by-step analysis of the process by which a person identifies with an occupation, see Howard $\mathrm{S}$. Becker and James W. Carper, "The Development of Identification with an Occupation," American Journal of Sociology, LXI (January 1956), 289-98. 
hand, is roughly the reverse.$^{33}$ What comes very clearly in all this is that the prospective subject specialist acquires the ideology of his specialty while still in school. At the other pole, it seems that the potential librarian is not subject to this kind of initiation either as an undergraduate or as a student in a graduate library school. The socialization of the librarian takes place mainly on the job. In the case of the academic librarian, particularly, the ideology is acquired in the working library environment rather than during the period of formal training for librarianship.

From the preceding it is apparent that there is great variance between the images of the academic librarian and the classroom teacher. Whereas the professor's training stresses intellectual competence, that of the librarian still emphasizes technical and procedural capacities. The professor may be viewed as impulsive, changeable, sensitive, and volatile. ${ }^{34}$ The librarian, at the other extreme, is usually more ordered, conservative, and conformist. Dean Robert Douglass, whose assessment of librarian personality has been widely recognized, has said of librarians: "Many of the traits which characterize the modal librarian ... . are not those most closely associated with or predictive of forceful leadership, distinguished scholarship, imaginative research, or other highly creative attainment." 35 While it is probably true that librarians become administrators because their personality profiles depart from this mode, nevertheless one wonders about the feasibility of Edward

ss See Donald L. Thistlethwaite, "Fields of Study and Development of Motivation to Seek Advanced Training," Journal of Educational Psychology, LIII (April 1962), 57. See also David Gottlieb, "The Socialization Process in American Graduate Schools" (PhD dissertation, Department of Education, University of Chicago, 1960). Gottlieb discovered that student changes in career preference are related to faculty contacts and specific departmental climates. His sample included 2842 students in twenty-five graduate schools.

s David C. Beardslee and Donald D. O'Dowd, "Students and the Occupational World" in Sanford (ed.), op. cit., p. 615 .

as Robert R. Douglass, "The Personality of the Librarian" (PhD dissertation, Graduate Library School, University of Chicago, 1957), p. 125.
Holley's argument that "the librarian who does not spend as much time outside the library as he does at his desk the first year on the job is already in serious trouble." 36 To spend considerable time in the offices of professors and deans is an excellent ideal for librarians, but it is not clear whether contemporary library administrators have, in general, either the personality characteristics or the knowledge background to make such initiatives effective. Even at Monteith College of Wayne State University, where deliberate effort is made to encourage faculty-librarian interaction, it was discovered that the librarians (most of whom are social scientists working on a project with a social science orientation) could develop only tangential relations with the humanities and natural science faculties. ${ }^{37}$ Even planning does not automatically insure colleagueship. It may be that the most fruitful relationships will develop between institutionoriented librarians (most are) and institution-oriented professors (few, unfortunately, are).

Librarians should never forget that an academician's most important contacts are his students and his teaching colleagues. Librarians, for the most part, tend to occupy a position of marginality in the faculty's network of communication. ${ }^{38}$ One could surmise that librarianfaculty "feedback" is often weak ${ }^{39}$ because of the competition librarians face in communicating with the faculty. Although the chief client of the academic

\footnotetext{
se Edward G. Holley, "Effective Librarian-Faculty Relationships," Illinois Libraries, XLIII (December 1961), 733 .

${ }^{3}$ An Experiment in Coordination between Teaching and Library Staff for Changing Student Use of a University Library (Project \#874-Report \#32, 1 Febru. ary 1961 to 30 June 1962 [Detroit: Monteith College of Wayne State University, 1962]), p. 6.

38 One reference librarian has lamented that "profes. sors do not imagine that librarians contemplate or have reason to contemplate the work of the university." See Abraham N. Barnett, "The Professor and the Librar. ian: The View from the Reference Desk," Liberal Education, XLV (May 1959), 243.

$\approx$ For a summation of the state of librarian-faculty "feedback," see Donald D. Ranstead, "'Feedback' to Faculty," Library Journal, LXXXVII (January 15, 1962), 172 .
} 
librarian is unquestionably the teacher, ${ }^{40}$ the academician usually looks upon any relationship with a librarian as peripheral to his main associations with students and other teachers. As a university becomes more cosmopolitan, opportunities for faculty-librarian communication probably decline. George Stern and C. Robert Pace, while protesting the College Characteristics Index, discovered that 65 per cent of the students at the highly cosmopolitan University of Chicage perceived student-faculty contacts, while at an unidentified municipal college, only 23 per cent had such perceptions. ${ }^{41}$ Professors at Chicago probably have very little time to develop working relationships (either formal or informal) with librarians. When they are not occupied with research or teaching, they are most likely busy apprenticing students in their specialty ${ }^{42}$ and, during their few intermissions, associating with their teaching peers. ${ }^{43}$

The task we face in developing colleagueship with our teaching brethren is a monumental one, not one which will in any way be solved by borrowing status symbols (e.g., faculty rank). ${ }^{44}$ The problem is doubtless aggravated by the presence in academic librarianship of a great

40 Knapp, loc. cit., p. 70.

4 Allen H. Barton, Organizational Measurement and Its Bearing on the Study of College Environments (New York: College Entrance Examination Board, 1961), p. 36.

${ }^{42}$ Joseph Katz has noted that "the implicit model of the majority of college teachers seems to be one according to which they see themselves at their various stalls in the fair of knowledge, hopefully attracting the students who have interest and aptitude for the teacher's specialty." See Joseph Katz, "Personality and Interpersonal Relations in the Classroom" in Sanford (ed.), op. cit., pp. 366-67. Riesman has suggested that an important function of the faculty is to "socialize the students into scholarship or some comparable ideal. ..." See his "The Influence of Student Culture and Faculty Values in the American College" in The Yearbook of Education (Yonkers-on-Hudson, New York: World, 1959), p. 392. Riesman and Christopher Jencks extend this conception in a later essay, in which the college experience is seen as an initiation rite (with the faculty as gatekeepers) separating the upper from the lower middle class. See their "The Viability of the American College" in Sanford (ed.), op. cit., p. 78 .

" Riesman, "The College Professor," in Blanshard, op. cit., p. 282 .

44 Philip H. Ennis suggests, and I agree, that this borrowing is largely a consequence of the profession's failure functionally to differentiate the work of the number of women. While these women, in general, are fully as qualified as their male counterparts, they are, notwithstanding, at some disadvantage in the matter of developing colleague associations with male professors. Recently the woman director of a medium-sized university library related that it is a distinct disadvantage not to be able to participate in the academic decision-making which goes on over the poker table. ${ }^{45}$ It is possible, of course, for academic librarians partially to solve this problem through active participation in the American Association of University Professors (AAUP). Interestingly enough, the ALA is an organization dominated by managers (i.e., chief librarians) while the AAUP has remained primarily an employee organization (i.e., it is controlled by nonadministrative faculty personnel). Since most academic librarians would be classed with the "managed" rather than the "managers," the AAUP as a viable organization for librarians has intriguing possibilities. ${ }^{46}$

Perhaps faculty-librarian integration can take place most pervasively in a college where librarians are teachers (as is

professional librarian from that of the nonprofessional. See his "Seven Questions About the Profession of Librarianship: Introduction," Library Quarterly, XXXI (1961), 303. Jane Forgotson, in an excellent article, has warned that if academic libraries become too hierarchical in structure, faculty members will not consider associating with any librarians who are not at the top of the hierarchy. See her "A Staff Librarian Views the Problem of Status," CRL, XXII (July 1961), 278.

is The position of female librarians vis-a-vis faculty men is somewhat analogous to that of the woman graduate student. Esther Raushenbush writes this of a Sarah Lawrence graduate: "This academic climate was described to me by a woman who does have staying power and is now doing research at a great graduate school: "All the men here are extremely cordial and helpful to me and the other mature women who are obviously in the game for keeps. But they are openly prejudiced against undertaking the education of women because women do not in fact make contributions worthy of the time invested in them.'" See Esther Raushen. bush, "Second Chance: New Education for Women," Harper's, CCXXV (October 1962), 148.

46 James A. Perkins has observed that, unlike the organization of an industrial plant, the academic hierarchy is discontinuous and that professorial responsibility is far less clear than administrative responsibility. See James A. Perkins, "Moral Judgments in Academic Structures" in Harlan Cleveland and Harold Lasswell (eds.), Ethics and Bigness: Scientific, Academic, Religious, Political, and Military (New York: Harper, 1962), pp. 85-86. 
the librarian-tutor at St. John's College in Annapolis) and teachers are librarians. This ideal is not new. It traces back at least as far as the library at Alexandria in Egypt and was championed in the 1930's by Louis Shores and B. Lamar Johnson. Last summer Robert Jordan of the Council on Library Resources unveiled his design for a library-college which would be one of twenty to forty autonomous institutions associated with a college host center equipped with library, laboratory, and other research facilities. ${ }^{47}$ In Jordan's scheme, the librarian-teacher would teach one-third of the time and devote the rest of his time to providing bibliographic assistance to a team which would also include four teachers and a contingent of students. Each regular (i.e., orthodox) faculty member would be required to allocate one-sixth to two-thirds of his time to librarianship or some other nonteaching or nonresearch activity. ${ }^{48}$ This return to the Oxford model of university organization, while magnifying the importance of the librarian's role, will require librarians with competencies far exceeding those now provided the student in a graduate school of librarianship.

Reference has already been made to the demise, within the university, of the community of scholars. Despite the advent of interdepartmental programs, one suspects that communication among subject specialists in a university is at a minimum. ${ }^{49}$ Graduate students seem extremely reluctant to take their doctorates in American Studies or the History of Ideas or in any other interdisciplinary program because of their genuine fear that such a degree does not guarantee a satisfactory academic position. ${ }^{50}$ Entre-

47 Robert T. Jordan, "The College Host Center and the Library-College," in Robert T. Jordan (ed.), The College Talkshop: A Summary of the Discussions at Kenyon College, June 24-29, 1962 (Washington: Council on Library Resources, 1962), pp. 23-24.

48 Ibid., p. 27

40 Joseph Katz, loc, cit., p. 377.

so Theodore Solotaroff," "The Graduate Student: A Profile," Commentary, XXXII (December 1961), 489. preneurs with narrowly specialized training have replaced more humane scholars on campus, and too often the university professor's commitment to his home institution is just about the inverse of the average IBM executive's loyalty to his company. ${ }^{51}$ After squeezing the customary scholarly articles out of his dissertation, the young academician often moves into foundation or governmentsupported project research. Professors, particularly those in the consensual disciplines (e.g., mathematics, the natural sciences, and the applied sciences), ${ }^{52}$ are no longer regarded as members of a small deviant minority, despite their continuing display of minority attitudes..$^{53}$ Although as a group the natural scientists receive the best support and are perhaps the most concerned about publish-

\footnotetext{
51 Fred B. Millett has imagined this encounter between a mid-twentieth century professor and a counterpart from the early nineteenth century: "If Arthur Bowditch Clark, Head of the Department of Economics at Harvard in 1960, were to encounter his lineal ancestor, Asa Bowditch Chadwick, Professor of Greek and an influential member of the faculty in 1812, both men might find the meeting a little disconcerting. After they had given due attention to their family history, explored their common interest in teaching, in students, and in colleges, and discovered that they combined a professed devotion to the university with a critical view of its president they might not find it easy to hit upon other topics of conversation. The younger man might be a little put off by his ancestor's semi-clerical attire, his decorous manner and his measured, if not oracular, utterance. $\mathrm{He}$ might be astounded to learn that the older man had taught not only Greek but mathematics and Christian evidence. The older men might find that his descendent's appearance could hardly be distinguished from that of a successful businessman and that his manner. was informal, if not casual. He might be puzzled by the narrowness of the younger man's intellectual interests, his professional pre-occupation not with the field of economics but with that of taxation, hardly, he might feel, a proper subject for university education." See Fred B. Millett, Professor: Problems and Rewards in College Teaching (New York: Macmillan, 1961), pp. 1-2. See also David Riesman, "Planning in Higher Education. Some Notes on Patterns and Problems," p. 13.

${ }_{52}$ The consensual disciplines, according to Frank Pinner of Michigan State, are those "with respect to which the public at large tends to have no reservations, either as to the competence of the scholars and the truth of their findings or as to the values which inform their work." The dissensual disciplines, on the other hand, are those "whose values or procedures are widely questioned among the public, either explicitly or implicitly." See Frank Pinner, "The Crisis of the State Universities: Analysis and Remedies," in Sanford (ed.), op. cit., p. 943.

5 Melvin Seeman, "The Intellectual and the Language of Minorities," American Journal of Sociology,
} LXIV (July 1958), 28-32. 
ing the results of research, Riesman has noted that "professors in the social sciences pass judgment on each other in terms that would not be different if they were engaged in production control. They speak of a man's 'output' or his 'productivity' as measurable and even quantifiable things, and yards of print take the place of foot-pounds or BTU's." 54

In 1958-59, most of the endowed universities received from 25 to 88 per cent of their income from government contracts of some kind. ${ }^{55}$ The changes which universities have undergone as a consequence of state and federal involvement are well described by M. K. Hubbert, a visiting professor of geology at Stanford University:

Instead of remaining primarily educational institutions and centers of fundamental inquiry and scholarship, the universities have become large centers of applied research. In fact, it is the boast of many that their highest paid professors have no teaching duties at all. Those of the first class, who bear the title "professor" and enjoy academic tenure, have largely become directors of research; those of the second class, whose competence often equals or exceeds that of the first class, are the research-project employees whose tenure extends from one contract to the next. As

\begin{tabular}{|c|c|c|c|}
\hline \multicolumn{4}{|c|}{$\begin{array}{l}\text { 54 David Riesman, "The Academic Career: Notes on } \\
\text { Recruitment and Colleagueship," Daedalus, LXXXVIII } \\
\text { (1959), 1955-56. } \\
\text { 55 Federal Contract Support of Representative En- } \\
\text { dowed Universities, 1958-1959 (From M. K. Hubbert, } \\
\text { "Are We Retrogressing in Science?," Science, CXXXIX } \\
\text { (March 8, 1963), 886-87.) }\end{array}$} \\
\hline & Total & Contract & Per Cent \\
\hline $\begin{array}{l}\text { UNIVERSITY } \\
\text { California In- }\end{array}$ & INCOME & In COME & Contracts \\
\hline $\begin{array}{l}\text { stitute of } \\
\text { Technology }\end{array}$ & $\$ 60,675,342$ & $\$ 53,600,442$ & 88 \\
\hline $\begin{array}{l}\text { Massachusetts } \\
\text { Institute of }\end{array}$ & & & \\
\hline $\begin{array}{r}\text { Technology } \\
\text { University of }\end{array}$ & $101,386,000$ & $67,276,000$ & 66 \\
\hline Chicago & $103,771,777$ & $61,531,262$ & 59 \\
\hline $\begin{array}{l}\text { Princeton } \\
\text { University }\end{array}$ & $31,563,000$ & $17,723,000$ & 56 \\
\hline Harvard & & & \\
\hline $\begin{array}{l}\text { University } \\
\text { Stanford }\end{array}$ & $67,292,489$ & $16,307,946$ & 24 \\
\hline University & $34,663,961$ & $8,312,208$ & 24 \\
\hline Rice University & $6,366,700$ & 633,500 & 10 \\
\hline Yale University & $36,985,998$ & 0 & 0 \\
\hline
\end{tabular}

an example of the inequities to which such a system leads, one might consider the following. The faculty of a given department in a certain university consists of $12 \mathrm{men}$, and the annual budget for 11 of these men is about $\$ 635,000$; the budget for the 12 th man, because of his superiority in the capture of government contracts, is $\$ 500,000 .^{56}$

There is a fear abroad in universities that scholars, particularly those who are attracted by the glitter of Big Science, will forsake the tradition of disinterested scholarship and become administrators, housekeepers, and publicists. ${ }^{57}$

Ours seems no less a manuscript culture than the Middle Ages, ${ }^{58}$ despite television's constant bombardment of our aural and visual faculties. Research has resulted in a complex division of labor in academe as indicated by the vast increase in the multiple authorship of articles appearing in the scholarly journals in the social sciences between 1920-55. ${ }^{59}$ So occupied are prominent professors with their research that they are often in residence no more than one term during the year. ${ }^{60}$ Increasingly, college teachers are losing their historic familism, and are often no more family-oriented than high status lawyers and doctors or wealthy industrialists. ${ }^{61}$ Even four-year institutions are taking on a research coloration. Already 73 per cent of the college students

se Ibid.

${ }^{57}$ Alvin M. Weinberg, "Impact of Large Scale Science on the United States," Science, CXXXIV (July $21,1961), 162$.

ss Walter J. Ong, S.J., Ramus: Method and the De. cay of Dialogue (Cambridge, Massachusetts: Harvard University Press, 1958), p. 308.

so William H. Whyte, Jr., The Organization Man (Garden City, N.Y.: Doubleday, 1956), p. 243. It is unlikely that the increase in multiple authorship can be accounted for by the recognition, on the part of senior men, of assistance which was not publicly acknowledged in an earlier period.

${ }^{60}$ Richard Armour of Scripps College has written, only half in jest, I am sure, that "of recent years, an increasing number of students spend their junior year abroad. This enables them to get a glimpse of professors who have been away for several years on Fulbrights and Guggenheims." See his From Sublimity to Ridicule: $A$ Short History of Education (New York: Editorial Projects for Education, 1962), p. 4.

"1 Riesman, "The College Professor," in Blanshard, op. cit., pp. $276-77$. 
in California are in junior and community colleges, and there is speculation that the upper divisions of the four-year colleges in that state will become semigraduate schools awarding the master's degree. At Carleton College, where a three-period year is in effect, faculty researchers have the option of not meeting classes at all if their projects or the need to travel are pressing. Additionally, some 143 liberal arts colleges, ranging from Abilene Christian and Antioch to Williams and Xavier of New Orleans, now offer work at the master's degree level. In a sample survey of forty-two of these colleges, the most common reply to the question, "To what extent was your library budget increased to meet the needs of the graduate program?" was that no distinction is made between the graduate and undergraduate programs in library appropriations, despite the fact that expert opinion is convinced that adequate library service for a quality graduate program should cost three to four times as much as the amount needed to support undergraduate programs in most subject fields. ${ }^{62}$

Another development of significance for academic librarianship is the proliferation of research institutes. In the social sciences, these institutes are frequently directed to refining methodological approaches to research. ${ }^{63}$ In his presidential address to the 1962 meeting of the American Sociological Association, Paul Lazarsfeld characterized the directors of social research institutes as "idea brokers," that is, persons who both seek grants for researchers and the right researchers for potential grants. Functionally, such institutes may be either specialized or general-purpose. Some are established for the sole purpose of facilitat-

\footnotetext{
Frederic W. Ness and Benjamin D. James, Grad uate Study in the Liberal Arts College (Washington: Association of American Colleges, 1962), pp. 108-109.

6s Paul F. Lazarsfeld, "The Sociology of Empirical Social Research," American Sociological Review, XXVII (December 1962), 757.
}

ing faculty research; others, with more autonomy, develop their own programs internally. ${ }^{64}$ With the research ethos well established almost everywhere, even in the good four-year colleges, librarians can properly serve clients doing research by acquiring a knowledge of how research proceeds and a kind of intuitive sensitivity to the needs of researchers. ${ }^{65}$ The prospect that library schools will be able to recruit and prepare research-conscious, subject-oriented librarians for academic libraries is mixed.

In the report of the president to the Carnegie Corporation in 1929, Frederick Keppel suggested that "the way should be made easy for able men with scholarly tastes and training in letters to shift from the overcrowded field of English teaching, or preparation therefor, to librarianship, where their intellectual qualifications and their sex combine to offer a bright professional future."66 Keppel's proposal that subject specialists might profitably enter the field of librarianship apparently did not, in the decade following 1929, gain the concurrence of those who ran library schools. At the beginning of World War II, Wilhelm Munthe wrote: "Applications with academic and specialized preparation were even regarded with a certain amount of skepticism. . . . Such training, it was said, would only divert its possessor from his library work or make him favor his own

\footnotetext{
S4 Ibid., pp. 763, 765 .

6 It seems to me that one cannot realistically demand that librarians become systematic researchers and writers. Many librarians, I am certain, become librarians because they are reluctant to accept the research responsibilities which are a concomitant of professorial life. The relative absence of worth-while empirical research in the library field impressed two sociologists who took part in the survey of librarianship in the Pacific Northwest. Kaspar Naegele and Elaine Stolar found our professional journals "not so much concerned with publishing research findings on technical matters, but rather place the emphasis on personal opinions of librarians regarding libraries, librarianship, and librarians." See their "The Librarian of the Northwest," in Morton Kroll (ed.), Libraries and Librarians of the Pacific Northwest (Seattle: University of Washington Press, 1960), pp. 126-27.

ee Report of the President and of the Treasurer of the Carnegie Corporation of New York (New York: Carnegie Corporation, 1929), p. 13.
} 
field." 67 At the present time, fortunately, there is a growing consensus among academic librarians and teachers of librarianship that there is indeed a need to produce librarians with greater subject competence.

Whether the majority of academic librarians in the future will be able to empathize with the "goings on" of research remains a moot question. There seems to be a tradition in librarianship which positively deters any iconoclastic attacks on the status quo. In her Introduction to Cataloging and the Classification of Books, Margaret Mann calls Dewey a genius, ${ }^{68}$ then warns her readers (most of whom undoubtedly have been students in library schools) that "to build an entirely new system for the classification of books is quite out of the question, unless one be a Bacon, a Spenser, or a Dewey."69 Statements of this kind do not inspire the type of innovation that results from the rejection of hero worship. Nor can the gradual erosion of research requirements for the master's degree in librarianship be interpreted favorably, particularly if one believes that to sympathize with research and to be aware of its problems the librarian, at some time in his career, must complete a sizeable piece of research.

On the positive side, persons with sound training in research are beginning to dominate the administrative positions in academic librarianship. Of the fortyfour persons who took doctorates in librarianship between June 30, 1959, and August 13, 1962, twenty-seven or 61 per cent are now associated with college or university libraries. ${ }^{70}$ Even if these holders of the doctorate do no further research of their own, it can at least be said

\footnotetext{
67 Wilhelm Munthe, American Librarianship from a European Angle: An Attempt at an Evaluation of Policies and Activities (Chicago: ALA, 1939), p. 139.

es Margaret Mann, Introduction to Cataloging and the Classification of Books (Chicago: ALA, 1930), p. 59.

Ibid., p. 60.

"0 Doctorates in Librarianship Granted Since June 30, 1959 (Berkeley: School of Librarianship, University of California, 1962).
}

that they will sympathize with the library problems of researchers. ${ }^{71}$ If the National Education Improvement Act of 1963 is passed, academic librarians may find it possible to obtain a good introduction to research in institutes for advanced study or in programs of specialized training, both of which are authorized in this bill. And, according to a recent prospectus, a possible element in the National Plan for Library Education is "the identification and exploration of the financing of research and development programs to insure basic and applied research adequate to support graduate library education and library operations." 72 One key to the emergence of the research-oriented academic librarian may rest with the library schools themselves. The ALA's recent decision to accredit single as well as multipurpose library schools leaves the way open for the establishment of library schools devoted exclusively to the preparation of academic librarians. It is in such a school that prospective academic librarians might acquire the subject knowledge and appreciation of research to be truly effective in their work. In the meantime, academic librarians already in the field could make the effort required of a good institutional citizen. Academic librarians generally can capitalize on their localism by practicing the fine art of "facultymanship," 73 that is, through more active participation in faculty meetings, on college committees, and in faculty clubs.

A prototype of the academic library of the future may well be found in the operational mode of the special library. As

71 In a letter to the author, dated December 10, 1962, Professor Everett Hughes of Brandeis University sug. gested that for the $\mathrm{PhD}$ in librarianship, the dissertation may end serious research. The dissertation, for educationists, social workers, and nurses, as well as librarians, may be looked upon, argues Hughes, as a kind of "master piece (in the sense of the guilds) which marks one's transition to full status as a master in his profession."

${ }^{2}$ Objectives of a National Plan for Library Education (Chicago: Library Education Division of the ALA, 1963), p. 3.

73 Arthur J. Dibben, "Facultymanship," Liberal Education, XLVIII (October 1962), 372, 379, 380-81. 
colleges and universities, with their associated research agencies, come to resemble more closely the research establishments of private corporations, academic libraries may, as a matter of course, model themselves after special libraries. The ferment in higher education may be best met by the development of a library dynamic. Dean Shera foresees, and one cannot help but agree, a shift in the traditional concept of library service and a new view of libraries as organizations "that reach out to the patron without waiting for his initiative."74 The experimental Park Forest (Illinois) College, scheduled to open in 1965, will have a bookless, ten-story library. Students, using $\$ 60$ microreaders of portable size, will be able to borrow, literally, "libraries" of material which has been miniaturized on film, cards, and slides. ${ }^{75}$ This kind of development is parallelled by the computerization of library operations. Computers give extension to the librarian's capacity to retrieve and manipulate information, but the computer, it should be recalled, is not anthropomorphic enough to create new knowledge. ${ }^{76}$ What computers mean to academic librarianship may be summarized in these two ways: (1) released from mechanical drudgery, librarians will have the opportunity to be more reflective and imaginative about the development of their profession, and (2) the leisure time which computers can provide will destroy any rationale which academic librarians, enmeshed in clerical work, may have had for their apparent anti-intellectualism. The mechanization of academic libraries, as a response to the extended and pressing literature needs of their users, may demand a complete reconfiguration of the discipline of librarianship as we now know it.

"Jesse H. Shera, "The Library of the Future," UNESCO Courier, XVI (January 1963), 13.

${ }_{75}$ "Two Additional Proposed Experimental Colleges," in Robert T. Jordan (ed.), op. cit., p. 47.

T6 Vern M. Pings, "The Spector of Automated Creativity," CRL, XXIV (March 1963), 124-25.
There is an evolving recognition that librarianship has its own area of human experience to analyze, its own body of descriptive and factual data to gather, and its own conceptual schemes to formulate and test for truth. It has been suggested elsewhere that our understanding of the physical aspects of library operation should be accompanied by equal insight into the socio-psychological foundations of librarianship. ${ }^{77}$ Librarianship, it may be argued, should abandon its historical-bibliographic emphasis for a base in the social sciences (particularly sociology, anthropology, social psychology, and political science). Shera's conception of a new discipline for librarianship, called social epistemology, would involve not only a systematic study of knowledge and the forms it assumes, but also substantial insight into the interaction between the body of knowledge and those in society who are seeking to use it. ${ }^{78}$

The experience with collaborative, interdisciplinary research, for example, may give us some hints as to how knowledge is best used in the academic setting. After studying one hundred senior scientists in a medical research organization, the Survey Research Center at the University of Michigan concluded that medical specialists, working in a team, are

\footnotetext{
\% See Daniel P. Bergen, "The Anthropocentric Needs of Academic Librarianship," CRL, XXIV (July 1963). Also my "Socio-Psychological Research on College Environments," CRL, XXIII (November 1962), 473-81.

78 Jesse Shera, "Social Epistemology, General Semantics, and Librarianship,"Wilson Library Bulletin, XXXV (June 1961), 769. Shera describes the relationship between general semantics and librarianship in the following way: ". . . librarianship and general semantics should be natural allies, closely interrelated, and converging at many points. Both are interdisciplinary to the highest degree, both are vitally concerned with the utilization of information by the human nervous system, both are important links in the communication chain, beth are deeply involved in language, symbolism, ab. straction, conceptualization, and evaluation. Both are fundamentally epistemological. To general semantics librarianship should contribute new insights into the structuring, organization, and availability of human knowledge. It can bring order and usability to a proliferation of recorded knowledge that threatens to become self-suffocating. To librarianship, general semantics should be able to contribute the fruits of social epistemology - the very foundation of the librarian's theoretical knowledge, lacking which librarianship degenerates from a profession to little more than a respectable trade." See ibid., p. 770.
} 
most content when they can have simultaneous contact with specialists in their own subjects and with others possessing different kinds of knowledge. ${ }^{79}$ Robert N. Rapoport, in his study of a collaborative relationship between sociologists and psychologists, learned that team research of that variety proceeded most smoothly when the autonomy of the representatives of the two disciplines was assured. ${ }^{80}$ Riesman has observed that productive colleagueships in universities often develop on other than disciplinary bases, though intra-disciplinary collaboration is by far the most common. Scholars in disparate disciplines are occasionally attracted to one another because of a common approach to knowledge. Generalizing historians and generalizing sociologists, for example, may have far more in common with each other than they do with the typical members of their own disci-

" Hollis W. Peter, "Human Factors in Research Administration" in Rensis Likert and Samuel P. Hayes (eds.), Some Applications of Behavioural Research (Paris: UNESCO, 1957), pp. 143-45.

so Effective organization of team research reminds one of governmental federalism. Just as political scientists hypothesize the development of a world federalism and the eventual emergence of a unified world state, so the promoters of interdisciplinary research might well insist on a federated team structure as preliminary to the type of unified group work which can develop only with a radical lowering of the walls separating disciplines. plines. ${ }^{81}$ Empirical research may yet reveal that strongly cosmopolitan scholars, with access to informal and free-flowing channels of information, may depend very little on the resources found in their local university libraries. Academic librarians, needless to say, will move closer to their teaching colleagues when they are better able to diagnose the manifold sources and kaleidoscopic uses of information.

While it would be senseless to urge, in conclusion, that contemporary academic libraries be modeled upon the ancient library at Alexandria, nevertheless academic librarians could do worse than pattern themselves after some of that institution's great librarians like Erastothenes the mathematician, or Callimachus the poet. ${ }^{82}$ Both of these men, as scholars, had an abiding interest in scholarship. Living as we do in an era of research and scholarship, should not our interest in such activities at least approximate that of our forebearers? The development of such an interest may be our way of narrowing the gap between subcultures.

${ }^{81}$ Riesman, "The Academic Career: Notes on Re. cruitment and Colleagueship," op. cit., pp. 160-61.

82 Leslie W. Dunlap, Alexandria: The Capital of Memory (Emporia: Kansas State Teachers College, 1963), p. 20.

\section{Subscriptions to Choice}

Following THE MEETING of the editorial board of CHOICE: Books for College Libraries in New York on October 15, the subscription rate for the new magazine, the first issue of which is expected in March 1964, is $\$ 20$ a year, $\$ 2.00$ a copy. Inquiries have been received at the editorial office as to whether the publication is part of ACRL membership. It is not; like ALA's Booklist, members and institutions will subscribe separately. CHOICE will be issued monthly, eleven times a year, with a combined July-August issue and cumulated index. Its annotations of two hundred twenty-five to three hundred books per issue will be directed toward the librarians and faculties of undergraduate four- and two-year colleges, and should be of value to librarians of public libraries, high schools and prep schools connected with accelerated programs for advanced students. It will materially aid in the selection of nonfiction and serious fiction, in both hard cover and quality paperback form, that are basic and significant for the liberal arts college curriculum. 